\title{
Safflower Evaluation under Contrasted Environment Conditions and Selection of Promising Genotypes
}

\author{
Lamyae Zraibi ${ }^{1}$, Miloud Kajeiou ${ }^{1}$, Hana Serghini Caid $^{1}$ and Abdelghani Nabloussi ${ }^{2}$ \\ 1. Laboratory of Plants and Microorganisms Biology, Biology Department, Faculty of Sciences, University of Mohamed Premier, \\ Oujda 60000, Morocco \\ 2. Research Unit of Plant Breeding and Plant Genetic Resources Conservation, National Institute for Agricultural Research, CRRA \\ of Meknes, Meknes 50000, Morocco
}

Received: February 21, 2014 / Published: April 20, 2014.

\begin{abstract}
Development of stable crops cultivars adapted to environmental constraints is very important for food security. Safflower, an oilseed crop which tolerates environmental abiotic stresses, is suitable for marginal lands relatively dry and deprived from fertilizer inputs or irrigation. A set of Moroccan and introduced cultivars as well as international accessions were conducted at Oujda (Eastern of Morocco) during 2009-2010 for late and conventional sowing under two water regimes, in a field experiment using a completely randomized design, with three replications. The objective was to evaluate the effect of genotype and contrasting environment on safflower behavior and to select genotypes with large adaptation to the contrasted environmental conditions. Morphological, physiological and agronomic traits, as well as the stress susceptibility index (SSI), were recorded in this study. Results showed significant effect of genotype, year (sowing time), water regime and their interaction on most of the studied parameters. Late sowing and drought affected negatively all the parameters except seed oil which lightly increased under drought stress. Number of heads per plant (NHP) had the strongest association with seed yield under both drought and non-drought conditions, and hence could be taken as selection criterion for safflower seed yield improvement. Five accessions showed the highest overall mean seed yield $(>1,000 \mathrm{~kg} / \mathrm{ha})$ and four accessions exhibited the highest overall mean seed oil content $(>310 \mathrm{~g} / \mathrm{kg})$. For late sowing, the accessions PI262421 and PI537604 produced the highest seed yield ( $>800 \mathrm{~kg} / \mathrm{ha})$ and the highest seed oil content $(>290 \mathrm{~g} / \mathrm{kg})$. For conventional sowing, the accessions PI250076 and PI250523 were the most performant, with a seed yield $>1,300 \mathrm{~kg} / \mathrm{ha}$ and a seed oil content $>330 \mathrm{~g} / \mathrm{kg}$. Based on their mean productivity across environments, their SSI and their MDA, PI271073 and PI250076 could be selected and used as promising germplasm in safflower breeding program in Morocco as well as other dry areas throughout the world.
\end{abstract}

Key words: Safflower, contrasted environments, NHP, seed yield, oil content, selection, promising genotypes.

\section{Introduction}

About $60 \%$ of agricultural production worldwide occurs in areas under some type of abiotic stress, producing only $15 \%$ to $20 \%$ of global food [1]. Therefore, the development of crops and stable cultivars adapted to environmental constraints is of paramount importance for food security. Among environmental constraints, water stress is one of the

Corresponding author: Abdelghani Nabloussi, Ph.D., research fields: oilseed crops breeding and genetics. E-mail: abdelghani.nabloussi@gmail.com. most harmful factors affecting crop production in dry areas [2]. Drought stress results in quantitative and qualitative changes in terms of various morphological, physiological, biochemical and agronomic parameters. These could be used as criteria for improving drought stress tolerance in different crops [3]. The use and breeding drought tolerant crops and cultivars in altered rainfall conditions may be required to stabilize agricultural production and insure food security. Also, improving crop tolerance to water limitation may be an important economical approach to reduce 
agricultural use of fresh water resources that are increasingly scarce [4]. Response to water stress is much complex and various mechanisms are adopted by plants encountering drought stress at various growth stages [5]. Water stress effects on plant growth and seed yield are genotype-dependent [6] and also depend on the timing, duration and magnitude of the water deficit [7].

Drought was always present in Morocco's history. Its importance as a structural element of the country's climate increased during the last decades, with a net reduction in the precipitation and an increasing temperature trend. The characterization of the climatic data during the period 1961-2004 showed increases in drought frequency, its severity and its spatial distribution $[8,9]$. Moreover, the North-Eastern region of Morocco, as well as other Mediterranean regions, is indeed characterized by low annual and irregular rainfall, with wide variations in seasonal and daily temperature.

Safflower (Carthamus tinctorius L.) is a tap-rooted annual crop which can tolerate environmental stresses including salinity and water stress [10]. Generally, safflower is produced on marginal lands that are relatively dry and relatively deprived from the benefits of fertilizer inputs or irrigation [11]. Safflower is a multi-purpose plant cultivated for edible oil, birdseed, spices, dye of its flowers, medicinal properties and ornamental use [12-14]. In Morocco, safflower cultivation, for oil production, was initiated in 1965 but has been abandoned since 1992, mainly for commercial reason. In fact, the production sale prices were not fixed and guaranteed as was the case for sunflower and rapeseed. Furthermore, during safflower cultivation period, seed yield and oil content remained very low due to the lack of adapted cultivars and poor management techniques used by farmers [15]. Recently, there has been a political will to restart and develop this crop, mainly for all areas of low rainfall, where the potential of other oilseed crops is more limited, through a global action plan including agricultural research. In this context, and in relation with breeding program, studies of impact of contrasting environment and climate change on safflower growth and productivity have been carrying out [15]. Indeed, climate change is particularly characterized by large fluctuation in the amount and frequency of rainfall events from year to year and between locations within years, even there is an increased drought trend. Thus, development of cultivars adapted to such environmental conditions is currently the most important objective of breeding programs in most countries of the world. Furthermore, among general concepts shared by breeding programs throughout the world, released varieties are based rather on their average performance in trials conducted in many environments than on their specific environment performance [1]. Thus, the handled germplasm should have broad adaptation to contrasting environments. Genotypes adapted to both stress and non-stress environments should be often selected. Mean productivity across environments and tolerance to environmental stress are indices that can be used to improve yield across a range of contrasting environments [16].

The present research was conducted to investigate the effect of different safflower genotypes and contrasting environments on some morphological, physiological, biochemical and agronomic traits, and to select genotypes with best performance, exhibiting broad adaptation under contrasting environments.

\section{Materials and Methods}

\subsection{Plant Materials}

This study concerned a total of 17 genotypes: 14 accessions and three cultivars from different geographic origins. One accession is from the Moroccan Gene Bank of INRA and 13 accessions were provided by the United States Department of Agriculture-Agricultural Research Service of Washington. The cultivar "Sharda" was introduced from India by the Moroccan Ministry of Agriculture. 
Table 1 shows the name/code, the nature and the origin of studied genotypes.

\subsection{Stress Treatment}

Tested genotypes were subjected to two water regime treatments applied during the growing season. Water regime 1 = full irrigation, throughout the crop cycle, to fully satisfy plant water needs. Water regime $2=$ partial irrigation or dry water regime in which irrigation was brought from the beginning of plant growth and then stopped at pre-flower bud stage until maturity. The second water regime was applied to simulate the drought most observed in Morocco in general and in the eastern region in particular, for winter crops like safflower, i.e., mid-season and terminal drought.

\subsection{Field Experiment}

The genotypes were planted in a sandy loam soil, $\mathrm{pH}$ 7.66, in the experimental farm of the "Centre de Qualification Agricole de Bouchtat" at Oujda city in

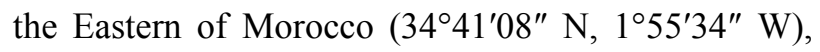
representing a semi-aride climatic zone. Each genotype was grown during two growing seasons,

Table 1 Code/name, nature and origin of the studied genotypes.

\begin{tabular}{lll}
\hline Code/name & Nature & Origin \\
\hline PI506426 & Accession & China \\
PI262421 & Accession & Australia \\
PI262418 & Accession & Australia \\
PI271073 & Accession & Australia \\
PI306685 & Accession & Israel \\
PI292000 & Accession & Israel \\
PI537705 & Accession & USA \\
PI537604 & Accession & USA \\
PI306838 & Accession & India \\
PI250523 & Accession & Egypt \\
PI306612 & Accession & Egypt \\
PI250076 & Accession & Egypt \\
PI306598 & Accession & Egypt \\
GBM9869 & Accession & Morocco \\
Cartafri & Cultivar & Morocco \\
Cartamar & Cultivar & Morocco \\
Sharda & Cultivar & India \\
\hline
\end{tabular}

2008/2009 and 2009/2010, in a single 3 m-length row. Inter and intra row spacing was $0.80 \mathrm{~m}$ and $0.30 \mathrm{~m}$, respectively. Given the limited amount of available seeds and in absence of any heterogeneity gradient at the experimental plot, the field experiment was conducted using a completely randomized design with three replications. A triple factorial model was used, and the tested factors were genotype, water regime and year (sowing time). All factors were taken as fixed. Late sowing (February 2009) and conventional sowing (December 2009) were done in 2008/2009 and 2009/2010 seasons, respectively.

\subsection{Contrasting Environments}

Environment 1: late sowing with full irrigation (without drought stress); environment 2: late sowing with partial irrigation (drought stress); environment 3: conventional sowing without drought stress; environment 4: conventional sowing with drought stress. During the growing season 2008/2009 (environment 1 and environment 2), rainfall was 250 $\mathrm{mm}$ and the mean temperature was $18.2^{\circ} \mathrm{C}$. During the growing season 2009/2010 (environment 3 and environment 4), rainfall was $306 \mathrm{~mm}$ and the mean temperature was $18.3{ }^{\circ} \mathrm{C}$. Furthermore, after stopping irrigation at the bud stage, and until maturity, plants growing in 2008/2009 were subjected to lower rainfall $(11 \mathrm{~mm})$ than those growing in 2009/2010 (37 mm). Therefore, plants growing in the former season were more stressed than those growing in the latter one.

\subsection{Parameters Measured}

Data were collected on morphological, physiological, agronomic and technological attributes. The plant height (PHT), measured from the ground to the top of the plant at the maturity, was expressed in $\mathrm{cm}$. Branching indicates the number of principal branches per plant (NBP), determined at the maturity. The leaf water content (LWC), expressed in $\mathrm{g} / \mathrm{kg}$ of fresh matter, was determined from leaves sample collected in full bloom stage and oven dried at $60{ }^{\circ} \mathrm{C}$ for $72 \mathrm{~h}$, using the 
following formula:

$$
\mathrm{LWC}=(\mathrm{FW}-\mathrm{DW}) / \mathrm{FW}) \times 100
$$

where, FW is the fresh weight of the sample and DW is the dry weight of the sample. Stressed plants have a chain of lipid peroxidation leading, at the end, to the production of malondialdehyde (MDA). MDA content, expressed in $\mathrm{nmol} / \mathrm{g}$ of fresh matter, was measured following the procedure performed and described by Hodges et al. [17]. Chlorophyll content (CLC) and carotenoid content (CDC), expressed in $\mathrm{mg} / \mathrm{g}$ of fresh matter, were determined in accordance with Lichtenthaler [18]. MDA, CLC and CDC were determined on leaves randomly collected at the end of flowering. The agronomic parameters measured after harvest were number of heads per plant (NHP), 1,000 seed weight (TSW), expressed in g, and seed yield (SYH), expressed in $\mathrm{kg} / \mathrm{ha}$. The technological parameter was seed oil content (SOC), expressed in $\mathrm{g} / \mathrm{kg}$ of dry matter, and it was determined by resonance magnetic nuclear (RMN). To evaluate the level of genotypes resistance to drought, the stress susceptibility index (SSI) was determined. According to Acevedo [19],

$$
\mathrm{SSI}=\frac{1-\left(\frac{Y d}{Y p}\right)}{1-\left(\frac{Y m d}{Y m p}\right)}
$$

where, $Y d$ is the seed yield of a tested genotype under drought conditions; $Y p$ is the seed yield under irrigated conditions of the tested genotype; Ymd is the trial average seed yield under drought conditions; Ymp is the trial average seed yield under irrigated conditions.

For computation of these parameters, and for each environment, a randomized sample of three plants by genotype was taken.

\subsection{Statistical Analysis}

Data were analyzed using GLM procedure of the statistics software SAS to test significant differences among genotypes, water regimes, years and their interactions. Duncan's new multiple range test was applied to compare treatment means at the 5\% probability level. Correlation procedure was also used to determine the correlation coefficients between the parameters.

\section{Results and Discussion}

\subsection{Effect of the Genotype, the Environment and Their Interaction on the Parameters Studied}

Highly significant differences were observed between genotypes for all parameters, except number of principal branches per plant (Table 2), indicating high genetic diversity among the tested genotypes. Also, highly significant differences were found between applied water regimes for all parameters, except plant height and branching (Table 2). This result is plausible given that there was no water stress before bud stage and then the both vegetative characters grew under the same conditions for all contrasting environments.

The overall average LWC was $826 \mathrm{~g} / \mathrm{kg}$, under full irrigation regime, and $718.8 \mathrm{~g} / \mathrm{kg}$, under drought conditions (partial irrigation). The MDA mean value was $3.9 \times 10^{-5} \mathrm{nmol} / \mathrm{g}$ and $9.9 \times 10^{-5} \mathrm{nmol} / \mathrm{g}$, respectively under non-drought and drought conditions. As it is known, plants under stress have a chain of lipid peroxidation leading, at the end, to the production and accumulation of MDA. In a previous study, involving the three cultivars tested in the present study, in addition to another Spanish cultivar "Rancho", we found an average MDA of $6 \times 10^{-5}$ $\mathrm{nmol} / \mathrm{g}$ for full irrigation conditions and $10^{-4} \mathrm{nmol} / \mathrm{g}$ for severe drought conditions [20], which is in agreement with the finding of the present research. In absence of water stress, average CLC was $0.63 \mathrm{mg} / \mathrm{g}$ and average CDC was $1.50 \mathrm{mg} / \mathrm{g}$, while under water stress, these values were $0.19 \mathrm{mg} / \mathrm{g}$ and $1.05 \mathrm{mg} / \mathrm{g}$, respectively. Our results demonstrated that the increase of MDA concentration in plant leaves is often associated with a decrease of CDC. In fact, carotenoids play an important role, as antioxidant, in cellular membrane protection by decreasing lipid oxidation $[21,22]$. Elevated levels of MDA are an 
Table 2 Analysis of variance (mean square and significance level of differences) for agro-morphological, physiological and agronomic parameters of 17 safflower genotypes evaluated in contrasted environments at Oujda during 2009 and 2010.

\begin{tabular}{|c|c|c|c|c|c|c|c|c|c|c|c|}
\hline \multirow[b]{2}{*}{ Source of variation } & \multirow{2}{*}{$\begin{array}{l}\text { Degree of } \\
\text { freedom }\end{array}$} & \multicolumn{10}{|c|}{ Parameters } \\
\hline & & PHT & NBP & LWC & $\begin{array}{l}\text { MDA } \\
\left(\times 10^{-9}\right)\end{array}$ & CLC & $\mathrm{CDC}$ & NHP & TSW & SYH & $\mathrm{SOC}$ \\
\hline Year (Y) & 1 & $\begin{array}{l}417,883.77 \\
* * *\end{array}$ & $\begin{array}{l}7,170.24 \\
* * *\end{array}$ & $\begin{array}{l}300.81 \\
*\end{array}$ & $\begin{array}{l}5.96 \\
* *\end{array}$ & $\begin{array}{l}15.30 \\
* * *\end{array}$ & $\begin{array}{l}243.22 \\
* * *\end{array}$ & $\begin{array}{l}36,068.16 \\
* * *\end{array}$ & $\begin{array}{l}26.15 \\
n s\end{array}$ & $\begin{array}{l}10,612,103.46 \\
* * *\end{array}$ & $\begin{array}{l}1,339.2 \\
* * *\end{array}$ \\
\hline Genotype (G) & 16 & $\begin{array}{l}1,044.49 \\
* * *\end{array}$ & $\begin{array}{l}240.60 \\
\mathrm{~ns}\end{array}$ & $\begin{array}{l}250.16 \\
* * *\end{array}$ & $\begin{array}{l}6.40 \\
* * *\end{array}$ & $\begin{array}{l}0.04 \\
* * *\end{array}$ & $\begin{array}{l}1.17 \\
* * *\end{array}$ & $\begin{array}{l}2,013.96 \\
* * *\end{array}$ & $\begin{array}{l}450.81 \\
* * *\end{array}$ & $\begin{array}{l}474,191.34 \\
* * *\end{array}$ & $\begin{array}{l}59.77 \\
* * *\end{array}$ \\
\hline Regime water (RW) & 1 & $\begin{array}{l}0.58 \\
\mathrm{~ns}\end{array}$ & $\begin{array}{l}111.76 \\
\mathrm{~ns}\end{array}$ & $\begin{array}{l}5,922.63 \\
* * *\end{array}$ & $\begin{array}{l}180 \\
* * *\end{array}$ & $\begin{array}{l}9.75 \\
* * *\end{array}$ & $\begin{array}{l}9.92 \\
* * *\end{array}$ & $\begin{array}{l}2,266.69 \\
* *\end{array}$ & $\begin{array}{l}741.23 \\
* *\end{array}$ & $\begin{array}{l}22,464,547.25 \\
* * *\end{array}$ & $\begin{array}{l}205.59 \\
* * *\end{array}$ \\
\hline $\mathrm{G} \times \mathrm{RW}$ & 16 & $\begin{array}{l}317.51 \\
* * *\end{array}$ & $\begin{array}{l}222.53 \\
\text { ns }\end{array}$ & $\begin{array}{l}228.57 \\
* * *\end{array}$ & $\begin{array}{l}3.69 \\
* * *\end{array}$ & $\begin{array}{l}0.17 \\
* * *\end{array}$ & $\begin{array}{l}0.93 \\
* * *\end{array}$ & $\begin{array}{l}973.96 \\
* * *\end{array}$ & $\begin{array}{l}163.24 \\
\text { ns }\end{array}$ & $\begin{array}{l}601,882.47 \\
* * *\end{array}$ & $\begin{array}{l}31.31 \\
* * *\end{array}$ \\
\hline $\mathrm{Y} \times \mathrm{G}$ & 16 & $\begin{array}{l}704.12 \\
* * *\end{array}$ & $\begin{array}{l}328.83 \\
\mathrm{~ns}\end{array}$ & $\begin{array}{l}1,223.33 \\
* * *\end{array}$ & $\begin{array}{l}6.75 \\
* * *\end{array}$ & $\begin{array}{l}9.31 \\
* * *\end{array}$ & $\begin{array}{l}4.24 \\
* * *\end{array}$ & $\begin{array}{l}463.13 \\
\text { ns }\end{array}$ & $\begin{array}{l}760.65 \\
* *\end{array}$ & $\begin{array}{l}806,565.18 \\
* *\end{array}$ & $\begin{array}{l}185.25 \\
* * *\end{array}$ \\
\hline $\mathrm{Y} \times \mathrm{RH}$ & 1 & $\begin{array}{l}516.86 \\
* * *\end{array}$ & $\begin{array}{l}195.08 \\
\mathrm{~ns}\end{array}$ & $\begin{array}{l}410.52 \\
* * *\end{array}$ & $\begin{array}{l}2.52 \\
* * *\end{array}$ & $\begin{array}{l}0.04 \\
* * *\end{array}$ & $\begin{array}{l}1.15 \\
* * *\end{array}$ & $\begin{array}{l}1,416.24 \\
* * *\end{array}$ & $\begin{array}{l}217.96 \\
*\end{array}$ & $\begin{array}{l}426,289.43 \\
* * *\end{array}$ & $\begin{array}{l}30.08 \\
* *\end{array}$ \\
\hline $\mathrm{Y} \times \mathrm{G} \times \mathrm{RH}$ & 16 & $\begin{array}{l}207.88 \\
* * *\end{array}$ & $\begin{array}{l}198.81 \\
\text { ns }\end{array}$ & $\begin{array}{l}260.60 \\
* * *\end{array}$ & $\begin{array}{l}3.08 \\
* * *\end{array}$ & $\begin{array}{l}0.15 \\
* * *\end{array}$ & $\begin{array}{l}0.82 \\
* * *\end{array}$ & $\begin{array}{l}1,036.07 \\
* * *\end{array}$ & $\begin{array}{l}231.52 \\
* *\end{array}$ & $\begin{array}{l}412,296.19 \\
* * *\end{array}$ & $\begin{array}{l}18.46 \\
\text { ns }\end{array}$ \\
\hline Error & 136 & 48.61 & 211.39 & 54.92 & 0.61 & 0.01 & 0.15 & 316.55 & 106.52 & $109,692.40$ & 12.95 \\
\hline
\end{tabular}

PHT: plant height (cm); NBP: number of branches per plant; LWC: leaf water content (g/kg); MDA: malondialdehyde content (nmol/g); CLC: chlorophyll content (mg/g); CDC: carotenoid content (mg/g); NHP: number of heads per plant; TSW: thousand seeds weight (g); SYH: seed yield per hectare $(\mathrm{kg} / \mathrm{ha})$; SOC: seed oil content $(\mathrm{g} / \mathrm{kg}) ;{ }^{*}, * *$ and $* * *$ significant at $0.05,0.01$ and $0.001 \mathrm{levels}$, respectively; ns: not significant.

indicator of membrane damages which are strongly linked to uncontrolled accumulation of reactive oxygen species (ROS) due to water stress [23]. The CLC decrease under drought stress had been also reported in previous studies on other crops like sunflower [24, 25]. Similarly, drought stress affected negatively NHP, TSW and SYH. The respective averages were 46.32 heads, $36.86 \mathrm{~g}$ and $594.43 \mathrm{~kg} / \mathrm{ha}$, being much lower than those observed in absence of water stress: 53.15 heads, $40.68 \mathrm{~g}$ and $1,195.11 \mathrm{~kg} / \mathrm{ha}$, respectively. These results demonstrated that mid and terminal drought stress is harmful for safflower productivity. Seed yield is drastically affected because of reduction of its components, NHP and TSW, in addition to number of seeds per head [20, 26, 27]. However, seed oil content seems to be stimulated by drought. The overall average was $305 \mathrm{~g} / \mathrm{kg}$, compared to $286 \mathrm{~g} / \mathrm{kg}$ observed in full irrigation conditions. This result is in disagreement with that found by Nabipour et al. [28]. In their study, they observed that seed oil content in safflower was reduced by drought occurring during bloom and maturity stages. Nevertheless, other reports indicated that moderate stress could either cause an increase of seed oil content $[29,30]$ or have no effect on it [31]. These contrasted findings are likely due to variation in environmental conditions of the experimental sites, differences in safflower genotypes tested and severity of drought stress applied in the experiments.

Likewise, the year factor affected significantly all parameters measured, except TSW. Because of its late planting date, the 2008/2009 growing season was less favorable than 2009/2010 growing season for all parameters. In this latter, higher values were obtained for PHT (164.95 cm), NBP (23.97), LWC (784.4 $\mathrm{g} / \mathrm{kg}$ ), CDC (2.97 mg/g), NHP (63.15), SYH (1,123.61 $\mathrm{kg} / \mathrm{ha})$ and $\mathrm{SOC}(321.30 \mathrm{~g} / \mathrm{kg})$, compared to those obtained in the former: PHT (74.43 cm), NBP (13.90), LWC (760.1 g/kg), CDC (0.18 mg/g), NHP (36.22), SYH $(665.23 \mathrm{~kg} / \mathrm{h})$ and SOC $(270.20 \mathrm{~g} / \mathrm{kg})$. Surprisingly, the CLC was higher in 2008/2009 (0.68 $\mathrm{mg} / \mathrm{g})$ than in $2009 / 2010(0.13 \mathrm{mg} / \mathrm{g})$. Both growing seasons were comparable for TSW even the first one exhibited an average (39.13 g) lightly higher than that of the second one $(38.41 \mathrm{~g})$. This indicates clearly that late planting is harmful to safflower growth and 
productivity, particularly in matter of seed yield and oil content. Similar findings had been reported in many other studies on planting date effect on various safflower parameters [32-35]. The planting date may affect the plant growth through changes in environmental conditions such as soil moisture, temperature and length of day during the growth season. Delay in planting date often makes plant growth in front of increased temperature and long day which shorten the duration of the vegetative period and therefore, decrease the growth, plant height and branching. Small safflower plants produce a reduced number of small heads containing a reduced number of seeds. Furthermore, late flowering associated to late planting could reduce the seed filling time period and the capacity for seed development and therefore could affect seed weight. Additionally, increased temperature and lack of water during late flowering period affect the pollination and fertility. Consequently, seed yield decreases drastically. Similarly, inconsistent grain filling and lipid biosynthesis under such conditions might reduce seed oil content.

$\mathrm{G} \times \mathrm{Y}$ and $\mathrm{G} \times \mathrm{Rw}$ interactions had a highly significant effect on all investigated parameters, except NBP for the former and NBP and TSW for the latter (Table 2). This indicates that, with respect to those parameters, genotypes reacted differently to planting date and water availability during flowering and early maturity stages. Similarly, $\mathrm{G} \times \mathrm{Rw} \times \mathrm{Y}$ interaction had a highly significant effect on all investigated parameters, except NBP and SOC (Table 2). This means that value and performance of tested genotypes changed according to the environment where they were growing. Our results are supported by those of other previous researches [34, 35].

In environment 1 , significant differences existed among genotypes for all parameters, except LWC, TSW and SOC (data not shown). The average SYH was $901.82 \mathrm{~kg} / \mathrm{ha}$ and the average SOC was 249.80 $\mathrm{g} / \mathrm{kg}$. Six genotypes yielded more than $1,000 \mathrm{~kg} / \mathrm{ha}$ : GBM9869, PI537604, PI506426, PI306598, PI262421 and PI306612. Three of them had the highest SOC (> 280 g/kg): PI537604, PI262421 and PI306612 (Fig. 1). In environment 2, genotypes were significantly different for all parameters (data not shown). The genotypes most interesting were PI262421 and PI306685 having a SYH $>700 \mathrm{~kg} / \mathrm{ha}$ and a $\mathrm{SOC}>$ $300 \mathrm{~g} / \mathrm{kg}$ (Fig. 1). Under late planting conditions, regardless applied water regime, i.e., combining environment 1 and environment 2, the most performant genotypes were PI262421 and PI537604 with a SYH $>800 \mathrm{~kg} / \mathrm{ha}$ and a SOC $>290 \mathrm{~g} / \mathrm{kg}$.

In environment 3, the genotype factor affected significantly all the parameters, except NBP (data not shown). Five genotypes were the most performant and produced at once a $\mathrm{SYH}>1,500 \mathrm{~kg} / \mathrm{ha}$ and a SOC $>330 \mathrm{~g} / \mathrm{kg}$ (Fig. 2). These were PI262421, PI306612, PI250523, PI250076 and PI271073. In environment 4 , there were significant differences among the tested genotypes for all the parameters (data not shown). Four genotypes (PI250076, PI271073, PI506426 and Sharda) yielded more than $1,000 \mathrm{~kg} / \mathrm{ha}$ and four genotypes (PI250523, PI306612, PI292000 and Cartafri) produced a SOC > $360 \mathrm{~g} / \mathrm{kg}$ (Fig. 2). Under conventional planting conditions, combining environment 3 and environment 4, PI250076 and PI250523 were the most productive, having a SYH $>1,300 \mathrm{~kg} / \mathrm{ha}$ and a $\mathrm{SOC}>330 \mathrm{~g} / \mathrm{kg}$. Results obtained in environments 2 and 4 confirmed that drought effects on growth traits, seed yield and oil content were genotype-dependent [6, 20, 36-38].

Combining all the contrasting environments, the overall PHT was $119.70 \mathrm{~cm}$ and the extreme values were $100.42 \mathrm{~cm}$ for "Sharda" and $132.92 \mathrm{~cm}$ for PI262418 (Table 3). The LWC varied from $659 \mathrm{~g} / \mathrm{kg}$ for "Cartafri" to $830 \mathrm{~g} / \mathrm{kg}$ for PI262421, with an average of $774.70 \mathrm{~g} / \mathrm{kg}$. Among tested genotypes, eight accessions and one cultivar (Sharda), having the highest values, were comparable and maintained a LWC over $785 \mathrm{~g} / \mathrm{kg}$ (Table 3). The average MDA was $6.8 \times 10^{-5} \mathrm{nmol} / \mathrm{g}$, with a variation from $4.6 \times$ 


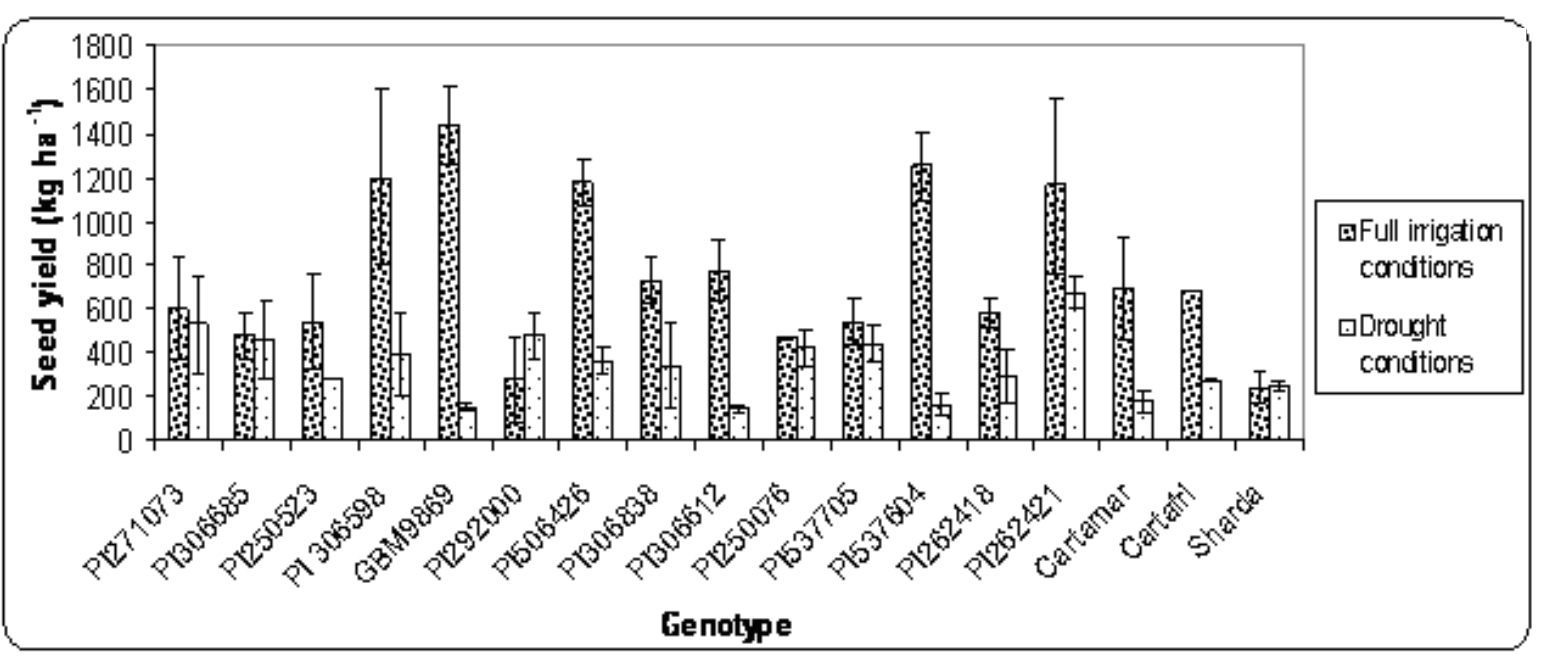

(a)

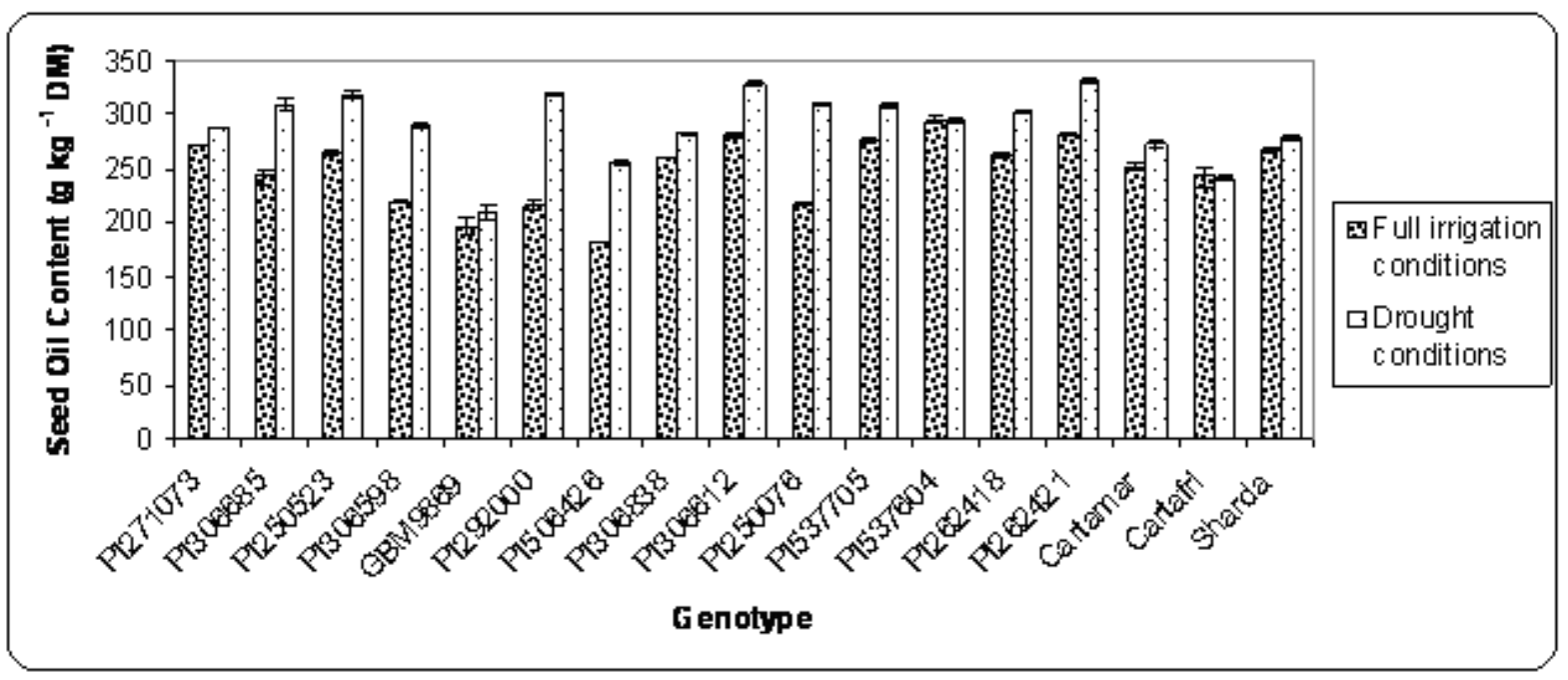

(b)

Fig. 1 (a) Seed yield and (b) seed oil content of 17 safflower genotypes grown under full irrigation and drought conditions at Oujda during 2009 (late sowing).

$10^{-5} \mathrm{nmol} / \mathrm{g}$ for PI262421 to $13.0 \times 10^{-5} \mathrm{nmol} / \mathrm{g}$ for "Cartafri". Eleven genotypes showed MDA values below the average (Table 3 ); eight of them exhibited a MDA level $<5.5 \times 10^{-5} \mathrm{nmol} / \mathrm{g}$ and therefore should be the most tolerant to drought conditions. LWC and MDA data indicated that the cultivar "Cartafri" would be the most sensitive to stress conditions whilst the accession PI262421 would be the most tolerant. CLC varied from $0.31 \mathrm{mg} / \mathrm{g}$ for PI306838 to $0.51 \mathrm{mg} / \mathrm{g}$ for PI271073 and the average was $0.41 \mathrm{mg} / \mathrm{g}$. Six accessions and one cultivar (Cartamar) had values above the average (Table 3 ). The $\mathrm{CDC}$ average was $1.28 \mathrm{mg} / \mathrm{g}$, exhibiting a large variation from $0.56 \mathrm{mg} / \mathrm{g}$ for "Cartamar" to $1.83 \mathrm{mg} / \mathrm{g}$ for PI537705. Eight accessions and one cultivar showed values above the average (Table 3). Regarding agronomic traits, the lowest NHP, 30.00, was observed for PI306612 and the highest one, 74.92, was observed for "Sharda". The overall average was 49.75 heads per plant. Three cultivars and just only three accessions performed a NHP above the average (Table 3). A large variability was revealed for TSW having a mean value of $38.77 \mathrm{~g}$. The minimum TSW was $29.85 \mathrm{~g}$ for PI306685 and the maximum TSW was $54.27 \mathrm{~g}$ for PI250523. The cultivar "Sharda" and seven other accessions produced big seeds with a TSW higher than the average (Table 


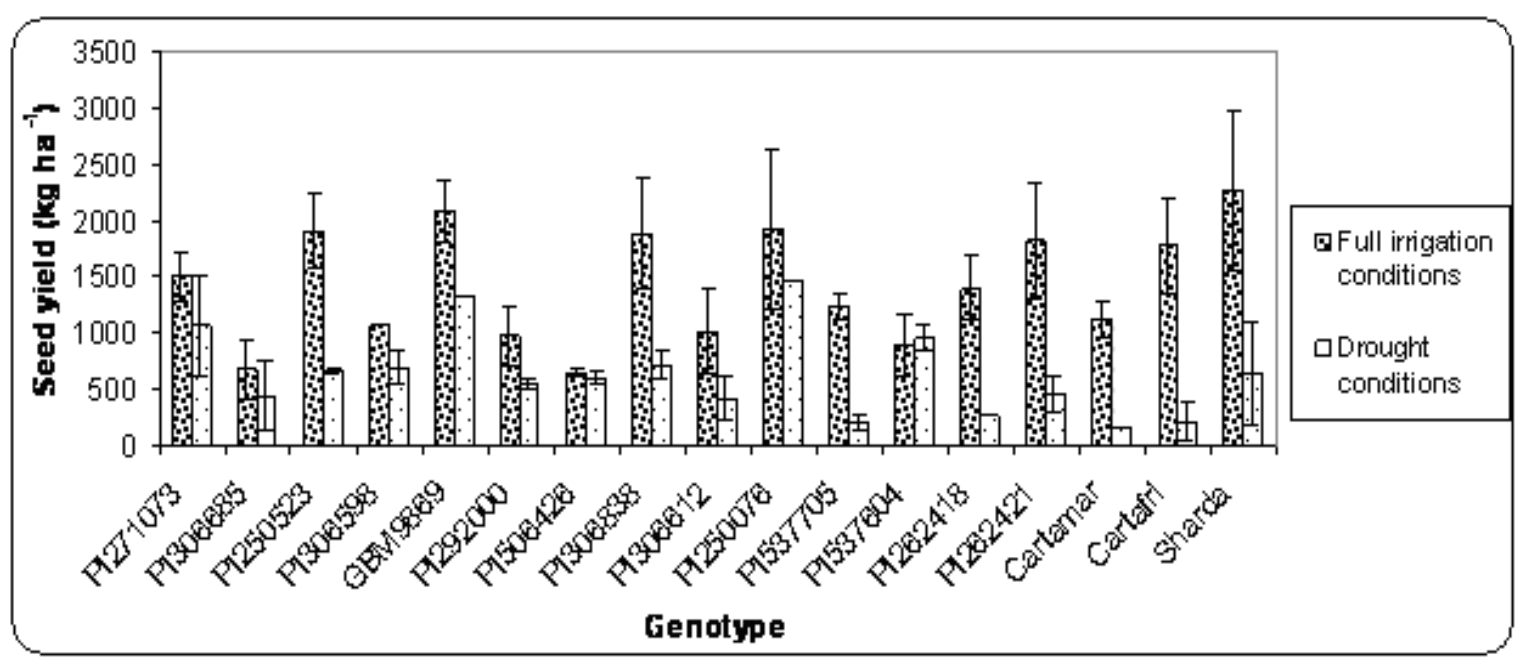

(a)

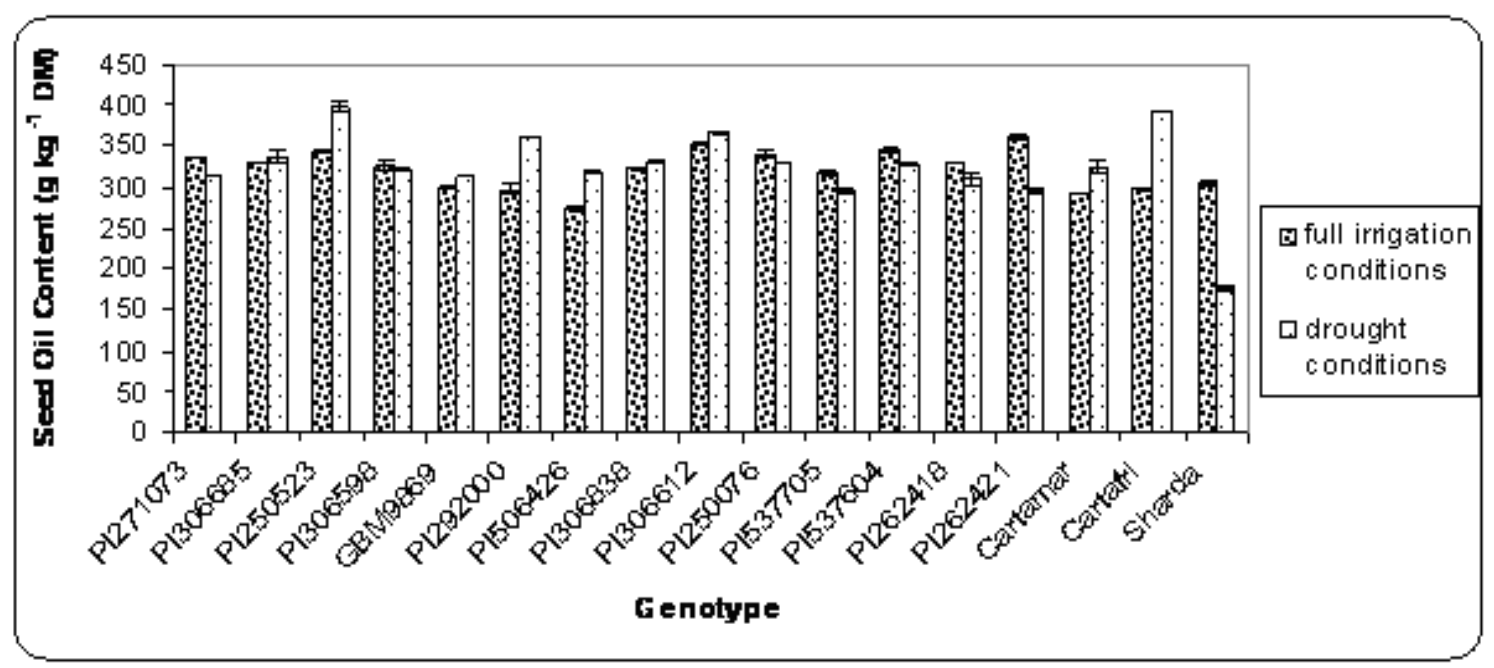

(b)

Fig. 2 (a) Seed yield and (b) seed oil content of 17 safflower genotypes grown under full irrigation and drought conditions at Oujda during 2010 (conventional sowing).

3). SYH was $893.29 \mathrm{~kg} / \mathrm{ha}$. The least productive genotype was the cultivar "Cartafri", yielding 513.60 $\mathrm{kg} / \mathrm{ha}$, whilst the most productive genotype was the accession GBM9869, yielding 1214.00 kg/ha. Only six genotypes had a SYH over the average, the accessions PI262421, PI271073, PI250076, PI306598 and GBM9869, and the cultivar "Cartamar". Duncan multiple range test revealed these five accessions were comparable for seed yield, being the most productive, with a $\mathrm{SYH}>1,090 \mathrm{~kg} / \mathrm{ha}$. All they had high to very high LWC, low to very low MDA, either low or high CLC, intermediate or high CDC and high to very high NHP (Table 3). Nevertheless, PI250076 had low NHP compensated by high TSW. The overall average seed oil content was $296.60 \mathrm{~g} / \mathrm{kg}$, with a large variation from $254.50 \mathrm{~g} / \mathrm{kg}$ for GBM9869 to $331.60 \mathrm{~g} / \mathrm{kg}$ for PI250523. Duncan multiple range tests showed that the accessions PI262421, PI537604, PI250523 and PI306612 were the best genotypes regarding SOC, with values higher than $315 \mathrm{~g} / \mathrm{kg}$ (Table 3). In general, these accessions exhibited high LWC, low MDA and high CDC.

Other reports had also shown a large genotypic variation for most of morphological, physiological, agronomic and technological traits. In our previous study on four varieties of safflower, LWC varied from $77 \mathrm{~g} / \mathrm{kg}$ 
Table 3 Average parameters values of 17 safflower genotypes grown under contrasting environments at Oujda in 2009 and 2010.

\begin{tabular}{llllllllll}
\hline Genotype & PHT & LWC & $\begin{array}{l}\text { MDA } \\
\left(\times 10^{-5}\right)\end{array}$ & CLC & CDC & NHP & TSW & SYH & SOC \\
\hline PI506426 & $121.42 \mathrm{cdef}$ & $81.25 \mathrm{a}$ & $6.39 \mathrm{defg}$ & $0.32 \mathrm{e}$ & $0.97 \mathrm{ef}$ & $48.00 \mathrm{def}$ & $41.66 \mathrm{bcde}$ & $868 \mathrm{cde}$ & $25.76 \mathrm{ef}$ \\
PI262421 & $118.67 \mathrm{ef}$ & $82.99 \mathrm{a}$ & $4.60 \mathrm{gh}$ & $0.46 \mathrm{abc}$ & $1.59 \mathrm{ab}$ & $66.42 \mathrm{ab}$ & $37.76 \mathrm{cdef}$ & $1158 \mathrm{abc}$ & $31.78 \mathrm{abc}$ \\
PI262418 & $132.92 \mathrm{a}$ & $79.43 \mathrm{ab}$ & $8.81 \mathrm{c}$ & $0.38 \mathrm{bcde}$ & $1.14 \mathrm{cdef}$ & $40.50 \mathrm{efg}$ & $41.43 \mathrm{bcde}$ & $751 \mathrm{ef}$ & $30.08 \mathrm{bcd}$ \\
PI271073 & $127.33 \mathrm{abc}$ & $79.40 \mathrm{ab}$ & $5.86 \mathrm{fgh}$ & $0.51 \mathrm{a}$ & $1.50 \mathrm{abc}$ & $49.67 \mathrm{cdef}$ & $33.34 \mathrm{def}$ & $1,196 \mathrm{ab}$ & $30.29 \mathrm{bcd}$ \\
PI306685 & $127.17 \mathrm{abc}$ & $78.06 \mathrm{bc}$ & $4.88 \mathrm{gh}$ & $0.45 \mathrm{abc}$ & $1.41 \mathrm{bcd}$ & $48.50 \mathrm{cdef}$ & $29.85 \mathrm{f}$ & $697 \mathrm{ef}$ & $30.47 \mathrm{bcd}$ \\
PI292000 & $126.25 \mathrm{bcd}$ & $72.93 \mathrm{~cd}$ & $6.26 \mathrm{efg}$ & $0.46 \mathrm{abc}$ & $1.07 \mathrm{def}$ & $37.42 \mathrm{efg}$ & $35.42 \mathrm{cdef}$ & $682 \mathrm{ef}$ & $29.89 \mathrm{bcd}$ \\
PI537705 & $106.25 \mathrm{~g}$ & $81.06 \mathrm{a}$ & $5.39 \mathrm{gh}$ & $0.49 \mathrm{ab}$ & $1.83 \mathrm{a}$ & $48.42 \mathrm{cdef}$ & $37.44 \mathrm{cdef}$ & $751 \mathrm{ef}$ & $29.93 \mathrm{bcd}$ \\
PI537604 & $120.42 \mathrm{def}$ & $78.28 \mathrm{bc}$ & $5.78 \mathrm{fgh}$ & $0.41 \mathrm{abcde}$ & $1.59 \mathrm{ab}$ & $38.92 \mathrm{efg}$ & $40.88 \mathrm{bcde}$ & $821 \mathrm{def}$ & $31.75 \mathrm{abc}$ \\
PI306838 & $121.42 \mathrm{cdef}$ & $77.79 \mathrm{bc}$ & $7.96 \mathrm{cdef}$ & $0.31 \mathrm{e}$ & $0.87 \mathrm{fg}$ & $46.50 \mathrm{defg}$ & $41.66 \mathrm{bcde}$ & $840 \mathrm{cdef}$ & $29.96 \mathrm{bcd}$ \\
PI250523 & $125.50 \mathrm{bcd}$ & $79.38 \mathrm{ab}$ & $5.57 \mathrm{gh}$ & $0.37 \mathrm{bcde}$ & $1.32 \mathrm{bcde}$ & $36.25 \mathrm{fg}$ & $54.27 \mathrm{a}$ & $893 \mathrm{bcde}$ & $33.16 \mathrm{a}$ \\
PI306612 & $125.08 \mathrm{bcde}$ & $72.23 \mathrm{cde}$ & $8.51 \mathrm{bcd}$ & $0.38 \mathrm{bcde}$ & $1.49 \mathrm{abc}$ & $30.00 \mathrm{~g}$ & $33.12 \mathrm{def}$ & $836 \mathrm{cdef}$ & $32.92 \mathrm{ab}$ \\
PI250076 & $129.58 \mathrm{ab}$ & $78.75 \mathrm{abc}$ & $4.71 \mathrm{gh}$ & $0.46 \mathrm{abc}$ & $1.09 \mathrm{def}$ & $36.17 \mathrm{fg}$ & $43.33 \mathrm{bc}$ & $1,095 \mathrm{abcd}$ & $29.32 \mathrm{bcd}$ \\
PI306598 & $117.42 \mathrm{f}$ & $68.99 \mathrm{de}$ & $8.40 \mathrm{bcde}$ & $0.33 \mathrm{de}$ & $1.19 \mathrm{cdef}$ & $54.33 \mathrm{bcde}$ & $38.22 \mathrm{cdef}$ & $1,129 \mathrm{abcd}$ & $28.96 \mathrm{cde}$ \\
GBM9869 & $123.50 \mathrm{bcde}$ & $79.56 \mathrm{abc}$ & $5.01 \mathrm{gh}$ & $0.36 \mathrm{cde}$ & $1.49 \mathrm{abc}$ & $59.42 \mathrm{abcd}$ & $42.12 \mathrm{bcd}$ & $1,214 \mathrm{a}$ & $25.45 \mathrm{f}$ \\
Cartafri & $105.17 \mathrm{~g}$ & $65.90 \mathrm{e}$ & $12.88 \mathrm{a}$ & $0.39 \mathrm{bcde}$ & $1.43 \mathrm{bcd}$ & $65.00 \mathrm{abc}$ & $32.05 \mathrm{ef}$ & $514 \mathrm{f}$ & $27.39 \mathrm{def}$ \\
Cartamar & $106.25 \mathrm{~g}$ & $78.35 \mathrm{bc}$ & $6.61 \mathrm{defg}$ & $0.44 \mathrm{abcd}$ & $0.56 \mathrm{~g}$ & $66.58 \mathrm{ab}$ & $31.62 \mathrm{ef}$ & $905 \mathrm{bcde}$ & $28.59 \mathrm{cdef}$ \\
Sharda & $100.42 \mathrm{~g}$ & $78.55 \mathrm{abc}$ & $10.35 \mathrm{~b}$ & $0.38 \mathrm{bcde}$ & $1.22 \mathrm{bcde}$ & $74.92 \mathrm{a}$ & $44.94 \mathrm{~b}$ & $821 \mathrm{def}$ & $25.67 \mathrm{ef}$ \\
\hline
\end{tabular}

PHT: plant height (cm); LWC: leaf water content (g/kg); MDA: malondialdehyde content (nmol/g); CLC: chlorophyll content (mg/g); CDC: carotenoid content (mg/g); NHP: number of heads per plant; TSW: thousand seeds weight (g); SYH: seed yield per hectare $(\mathrm{kg} / \mathrm{ha})$; SOC: seed oil content $(\mathrm{g} / \mathrm{kg})$; means followed by the same letters are not significantly different.

to $80 \mathrm{~g} / \mathrm{kg}, \mathrm{CDC}$ varied from $1 \mathrm{mg} / \mathrm{g}$ to $1.4 \mathrm{mg} / \mathrm{g}, \mathrm{CLC}$ varied from $0.18 \mathrm{mg} / \mathrm{g}$ to $0.25 \mathrm{mg} / \mathrm{g}$, MDA from $5 \times 10^{-5}$ $\mathrm{nmol} / \mathrm{g}$ to $15 \times 10^{-4} \mathrm{nmol} / \mathrm{g}$, NHP from 12 to 16 and TSW from $30 \mathrm{~g}$ to $54 \mathrm{~g}$ [20]. For all these parameters, the ranges of variation obtained in the present study were larger than those of the previous studies, because of the higher number of genotypes involved (17 vs. 4) and the experiment conditions (field experiment vs. pot experiment). In other previous study regarding morphological, agronomic and technological evaluation of a safflower collection consisting of 181 genotypes, including those tested in the present study, a large variability was found for all the characters. For $\mathrm{SYH}$, the observed variation was $250 \mathrm{~kg}$ /ha to 5,000 $\mathrm{kg} / \mathrm{ha}$, while for SOC, it was $230 \mathrm{~g} / \mathrm{kg}$ to $470 \mathrm{~g} / \mathrm{kg}$ [39]. These ranges of variation are much larger than those obtained in the present work because of the higher number of genotypes (181 vs. 17) and the experiment location conditions which were more favorable for the previous research. Other studies carried out in different locations in the world, the reported range for oil content was $270 \mathrm{~g} / \mathrm{kg}$ to $400 \mathrm{~g} / \mathrm{kg}$ [36-40], $214 \mathrm{~g} / \mathrm{kg}$ to $317 \mathrm{~g} / \mathrm{kg}$ [41] and $270 \mathrm{~g} / \mathrm{kg}$ to $360 \mathrm{~g} / \mathrm{kg}$ [33]. For seed yield content, various genotypic variations had been reported in different geographic environments: from $500 \mathrm{~kg} / \mathrm{ha}$ to $700 \mathrm{~kg} / \mathrm{ha}$ [42], $1,230 \mathrm{~kg} / \mathrm{ha}$ to $2,512 \mathrm{~kg} / \mathrm{ha}$ [33] and from $1,900 \mathrm{~kg} / \mathrm{ha}$ to $2,600 \mathrm{~kg} / \mathrm{ha}$ [34].

\subsection{Relationship between the Studied Parameters}

Table 4 shows the correlation coefficients between the parameters. The strongest relationship existed between CDC and PHT $(0.82, P<0.05)$, indicating that tall genotypes had elevated carotenoid content. Such genotypes exhibited reduced CLC, as a negative and significant correlation was between CLC and PHT $(-0.55, P<0.001)$ and between CLC and CDC $(-0.46$, $P<0.001)$. There was a strong, negative and significant correlation between MDA and LWC (-0.52, $P<0.001)$. This showed that low MDA, indicator of 
Table 4 Correlation coefficients between agromorphological, physiological and agronomic parameters of 17 genotypes evaluated in four contrasted environments at Oujda during 2009 and 2010.

\begin{tabular}{llllllllll}
\hline & CDC & MDA & LWC & PHT & NBP & NHP & TSW & SYH & SOC \\
\hline CLC & -0.46 & -0.27 & 0.24 & -0.55 & -0.25 & -0.20 & -0.07 & -0.06 & -0.46 \\
CDC & & -0.18 & 0.19 & 0.82 & 0.33 & 0.36 & 0.09 & 0.38 & 0.42 \\
MDA & & & -0.52 & -0.17 & -0.03 & -0.06 & -0.13 & -0.39 & -0.00 \\
LWC & & & & 0.19 & 0.07 & 0.05 & 0.13 & 0.29 & -0.04 \\
PHT & & & & & 0.37 & 0.36 & 0.05 & 0.37 & 0.50 \\
NBP & & & & & 0.22 & -0.00 & 0.26 & 0.26 \\
NHP & & & & & & & 0.00 & 0.61 & -0.02 \\
TSW & & & & & & & & 0.11 & 0.11 \\
SYH & & & & & & & & & \\
\hline
\end{tabular}

drought tolerance, was associated with high LWC under drought conditions. Drought tolerant genotypes were in general characterized by a high seed yield, as a negative and significant association was found between MDA and SYH $(-0.39, P<0.01)$. Genotypes with high seed yield were also characterized by high CDC $(0.38, P<0.01)$, tall plants $(0.37, P<0.01)$ and high LWC $(0.29, P<0.05)$. Johnson et al. [42] had also found a positive association between seed yield and plant height. However, NHP had the strongest association with SYH $(0.61, P<0.001)$, being one of its important agronomic components. Likewise, for the four contrasting environments, the highest correlation coefficients involving SYH, were those linking this latter to NHP. The found coefficients were $0.50(P<0.001)$ for environments 1 and 4, $0.38(P<$ $0.01)$ for environment 2 and $0.59(P<0.001)$ for environment 3 (data not shown). This result is in perfect agreement with that of a previous work showing that NHP recorded the highest positive and significant association with SYH [43]. The findings with respect to the association between seed yield and other traits confirmed those regarding the description of the most productive genotypes above. NHP was the most important trait contributing directly to seed yield under both drought and non-drought conditions. Thus, NHP could be taken as a selection criterion for seed yield improvement. On the other hand, seed oil content was positively and significantly correlated with $\mathrm{PHT}(0.50, P$ $<0.001)$ and $\operatorname{CDC}(0.42, P<0.01)$. Also, it was negatively and significantly correlated with CLC (-0.46, $P<0.001)$. Under environment 4 conditions, the positive and significant association between SOC and PHT was confirmed $(0.43, P<0.01)$. This indicates that with or without mid-season and terminal drought stress, taller genotypes tend to produce higher oil content.

\subsection{Resistance to Drought and Stability}

A large variation was observed among the genotypes for the SSI calculated for seed yield (Table 5). Genotypes with low SSI were considered to be more resistant to mid-season and terminal drought

Table 5 SSI of 17 safflower genotypes calculated for seed yield under drought and non-drought conditions during two years (2009 and 2010) at Oujda.

\begin{tabular}{lll}
\hline Genotype & $\begin{array}{l}\text { Year 2009 } \\
\text { (late sowing) }\end{array}$ & $\begin{array}{l}\text { Year 2010 } \\
\text { (conventional sowing) }\end{array}$ \\
\hline PI506426 & $1.32 \mathrm{a}$ & $0.13 \mathrm{~b}$ \\
PI262421 & $0.80 \mathrm{~b}$ & $1.41 \mathrm{a}$ \\
PI262418 & $0.96 \mathrm{a}$ & $1.54 \mathrm{a}$ \\
PI271073 & $0.25 \mathrm{~b}$ & $0.56 \mathrm{~b}$ \\
PI306685 & $0.09 \mathrm{c}$ & $0.64 \mathrm{~b}$ \\
PI292000 & $-1.38 \mathrm{c}$ & $0.84 \mathrm{~b}$ \\
PI537705 & $0.36 \mathrm{~b}$ & $1.60 \mathrm{a}$ \\
PI537604 & $1.67 \mathrm{a}$ & $-0.13 \mathrm{c}$ \\
PI306838 & $1.02 \mathrm{a}$ & $1.18 \mathrm{a}$ \\
PI250523 & $0.94 \mathrm{ab}$ & $1.22 \mathrm{a}$ \\
PI306612 & $1.57 \mathrm{a}$ & $1.11 \mathrm{a}$ \\
PI250076 & $0.19 \mathrm{~b}$ & $0.45 \mathrm{~b}$ \\
PI306598 & $1.30 \mathrm{a}$ & $0.66 \mathrm{~b}$ \\
GBM9869 & $1.73 \mathrm{a}$ & $0.68 \mathrm{~b}$ \\
Cartafri & $1.17 \mathrm{a}$ & $1.68 \mathrm{a}$ \\
Cartamar & $1.42 \mathrm{a}$ & $1.62 \mathrm{a}$ \\
Sharda & $-0.05 \mathrm{c}$ & $1.37 \mathrm{a}$ \\
\hline
\end{tabular}


than genotypes with high SSI. Four genotypes groups were identified in 2009 according to their drought resistance level ( $a, b, a b$ and $c$ ), as presented in Table 5. In 2010, three groups were identified ( $a, b$ and $c$ ). During 2009, under late sowing conditions, the accession PI292000 had the lowest SSI (-1.38) and thus was the most resistant to drought. The cultivar "Sharda" and the accession PI306685 were also respectively, and classified in the same group of drought resistant, having an index of -0.05 and 0.09 , PI292000 (group c). The genotypes PI271073, PI250076, PI537705 and PI262421, with relatively low SSI values $(<0.80)$, could be considered as moderately resistant. Genotypes as GBM9869, PI537604, PI306612, PI306598, "Cartamar" and "Cartafri”, exhibiting high SSI (> 1), belonged to the group (a) of the susceptible genotypes. The accession PI250523, with SSI of 0.94 could be considered as intermediate (Table 5). During 2010, with conventional sowing conditions, results showed that the accession PI537604 (group c) was the most resistant to drought stress, having the lowest SSI (-0.13). The accessions PI506426, PI250076, PI271073, PI306685, PI306598, PI292000 and GBM9869 (group b) were also drought resistant, exhibiting low SSI with values $<0.9$ (Table 5). The remaining genotypes were pooled in the group (a) of the susceptible material with SSI $>1.10$. The highest SSI values were observed for "Cartafri" (1.68), "Cartamar" (1.62) and PI537705 (1.60).

In general, results of both years were contrasted. One could observe stable genotypes which were either drought resistant or susceptible in both years and other instable genotypes which were resistant in one year and susceptible in the other. The most interesting for us are the accessions PI271073, PI306685, PI250076 and PI292000 which were stable regarding their resistance to mid-season and terminal drought under both conventional and late sowing conditions. However, average seed yield of PI306685 and PI292000 across tested environments were low (697 $\mathrm{kg} / \mathrm{ha}$ and $682 \mathrm{~kg} / \mathrm{ha}$, respectively). PI271073 and PI250076 were stable across environments and yielded over $1,090 \mathrm{~kg} / \mathrm{ha}$. Mean productivity across environments and tolerance to environmental stress are indices that can be used to improve yield across a range of contrasting environments [16]. Furthermore, both genotypes had a low MDA. Thus, PI271073 and PI250076 could be selected and involved in safflower breeding program in Morocco as well as other dry areas throughout the world.

\section{Conclusions}

Drought stress and late sowing affected significantly most of the agronomic, morphological and physiological traits evaluated. However, seed oil content seemed to be stimulated by drought. Also, a large genotypic variability was revealed for all the parameters. $\mathrm{G} \times \mathrm{Rw} \times$ Sowing time interaction had a highly significant effect on all investigated parameters, except branching and seed oil content. Under late sowing conditions, the most performant genotypes were PI262421 and PI537604, whilst under conventional sowing conditions, the genotypes PI250076 and PI250523 were the most productive. The accessions PI271073, PI306685, PI250076 and PI292000 were stable regarding their resistance to mid-season and terminal drought under both conventional and late sowing conditions. PI271073 and PI250076 being stable across environments and yielding over $1,090 \mathrm{~kg} / \mathrm{ha}$ were selected. These genotypes could be used in breeding programs both in Morocco and other safflower producer's countries in the world. High NHP, low MDA, high mean productivity across environments and low SSI could be used as selection criteria in safflower breeding program to improve yield across a range of contrasting environments.

\section{Acknowledgments}

The authors would like to thank Dr. Richard Johnson (USDA) for providing the safflower 
accessions used in this study. The "Center de Qualification Agricole de Bouchtat" at Oujda was also acknowledged for making at our disposal its experimental farm.

\section{References}

[1] S. Ceccarelli, Adaptation to low/high input cultivation, Euphytica 92 (1996) 203-214.

[2] J. Daneshian, D. Zare, Diversity for resistance drought on soybean, J. Agric. Sci. 1 (2005) 23-50.

[3] M. Ashraf, Inducing drought tolerance in plants: Recent advances, Biotechnol. Adv. 28 (2010) 169-183.

[4] N.N. Khamssi, K.G. Golezani, A. Najaphy, S. Zehtab, Evaluation of grain filling rate, effective grain filling period and resistance indices under acclimation to gradual water deficit stress in checkpea cultivars, Austr. J. Crop Sci. 5 (2011) 1044-1049.

[5] H. Jones, What is water use efficiency?, in: M.A. Bacon (Ed.), Water Use Efficiency in Plant Biology, Oxford, UK, 2004.

[6] M. Bannayan, F. Nadjafi, M. Azizi, L. Tabrizi, M. Rastgoo, Yield and seed quality of Plantago ovata and Nigella sativa under different irrigation treatments, Ind. Crops Prod. 27 (2008) 11-16.

[7] R.K. Pandey, J.W. Maranville, A. Admou, Tropical wheat response to irrigation and nitrogen in a Sahelian environment: I. Grain yield, yield components and water use efficiency, Eur. J. Agron. 15 (2001) 93-105.

[8] L. Stour, A. Agoumi, Climatic drought in Morocco during the last decades, Hydroecol. Appl. 16 (2008) 215-232.

[9] M. Benassi, Drought and climate change in Morocco: Analysis of precipitation field and water supply, Opt. Méditer. 80 (2009) 83-86.

[10] S. Lovelli, M. Perniola, A. Ferrara, T. Di Tommaso, Yield response factor to water $(K y)$ and water use efficiency of Carthamus tinctorius L. and Solanum melongena L., Agric. Water Manage. 92 (2007) 73-80.

[11] A. Nabloussi, L. Velasco, J.M. Fernandez-Martinez, Cross pollination of safflower under Moroccan environmental conditions, Int. J. Plant Breed. 7 (2013) 145-147.

[12] H.H. Mündel, R.J. Morrison, R.E. Blackshaw, B. Roth, Safflower production on the Canadian prairies, Alberta Agric. Res. Inst. Edmonton, Canada, 1992.

[13] A.M. Johnston, D.L. Tanaka, Oilseed crops for semiarid cropping systems in the Northern great plains, Agron. J. 94 (2002) 231-240.

[14] J. Uher, Safflower in world floriculture: A review, Sesame Safflower Newsl. 20 (2005) 76-80.

[15] A. Nabloussi, M. Boujghagh, Safflower breeding in
Morocco: History and current situation, Sesame Safflower Newsl. 21 (2006) 84-87.

[16] T. Hohls, Conditions under which selection for mean productivity tolerance to environment stress or stability should be used to improve yield across a range for contrasting environments, Euphytica 120 (2001) 235-245.

[17] D. Hodges, J.M. DeLong, C.F. Forney, R.K. Prange, Improving the thiobarbituric acid-reactive-substances assay for estimating lipid peroxidation in plant tissues containing anthocyanin and other interfering compounds, Planta 207 (1999) 604-611.

[18] H.K. Lichtenthaler, Chlorophylls and carotenoids: The pigments of photosynthetic biomembranes, Methods Enzym. 148 (1987) 350-382.

[19] E. Acevedo, Improvement of winter cereals in Mediterranean environments, use of yield, morphological and physiological traits, in: Physiology-Breeding of Winter Cereals for Stressed Mediterranean Environments, INRA-ICARDA, Montpellier, France, 1991, pp. 273-306.

[20] L. Zraibi, A. Nabloussi, J. Merimi, M. Kajeiou, A. El Amrani, A. Mihamou, et al., Effect of moisture stress on morphological, physiological and agronomic parameters of different safflower (Carthamus tinctorius) varieties, J. Oilseed Res. 29 (2012) 210-214.

[21] V. Böhm, N.L. Puspitasari-Nienaber, M.G. Ferruzzi, S.J. Schwartz, Trolox equivalent antioxidant capacity of different geometrical isomers of $\alpha$-carotene, $\beta$-carotene, lycopene and zeaxanthin, J. Agric. Food Chem. 50 (2002) 221-226.

[22] L. Müller, K. Fröhlich, V. Böhm, Comparative antioxidant activities of carotenoids measured by ferric reducing antioxidant power (FRAP), ABTS bleaching assay ( $\alpha$ TEAC), DPPH assay and peroxyl radical scavenging assay, Food Chem. 129 (2011) 139-148.

[23] F. Cai, L.J. Mei, X.L. An, S. Gao, L. Tang, F. Chen, Lipid peroxidation and antioxidant responses during seed germination of Jatropha curcas, Int. J. Agric. Biol. 13 (2011) 25-30.

[24] S.P. Kiani, P. Maury, A. Sarrafi, P. Grieu, QTL analysis of chlorophyll fluorescence parameters in sunflower (Helianthus annuus L.) under well-watered and water stressed conditions, Plant Sci. 175 (2008) 565-573.

[25] A. Massacci, S.M. Nabiev, L. Pietrosanti, S.K. Nematov, T.N. Chernikova, K. Thor, et al. Response of the photosynthetic apparatus of cotton (Gossypium hirsutum) to the onset of drought stress under field conditions studied by gas exchange analysis and chlorophyll fluorescence imaging, Plant Physiol. Biochem. 46 (2008) 189-195.

[26] M. Rostami, Effect of late-season drought stress on yield and physiological traits of wheat cultivars and determination of best drought-resistance index, M.Sc. 
Thesis, Depart. Agric., Ferdowsi Univ., Mashad, Iran, 2004.

[27] A. Tavakoli, Study on effect of irrigation withdrawal at different growth stages on yield, yield components and oil yield of safflower, M.Sc. Thesis, Depart. Agric., Tehran Univ., Tehran, Iran, 2004.

[28] M. Nabipour, M. Meskarbashee, H. Yousefpour, The Effect of Water Deficit on Yield and Yield Components of Safflower (Carthamus tinctorius L.), Pak. J. Biol. Sci. 10 (2007) 421-426.

[29] I. Hamrouni, H.B. Salah, B. Marzouk, Effect of water deficit on lipids of safflower aerial parts, Phytochemistry 58 (2001) 277-280.

[30] M. Rajab, N.A. Mahali, J. Carapetian, Effect of water stress on the amount of seed oil in different lines of safflower (Carthamus tinctorius L.), Ann. Biol. Res. 4 (2013) 183-189.

[31] A.N. Hang, D.N. Evans, Deficit sprinkler irrigation of sunflower and safflower, Agronomy J. 77 (1985) 588-592.

[32] H. Bagheri, R. Saeedi, E. Zaeh, Evaluation of agronomic traits of selected genotypes from safflower mass native in the spring and summer planting, Agric. Technol. Sci. Nat. Resour. 10 (2006) 375-390.

[33] E. Esendal, B. Arslan, C. Pasa, Effect of winter and spring sowing on yield and plant traits of safflower (Carthamus tinctorius L.), in: Proc. 7th Int. Safflower Conf., Wagga Wagga, Australia, Nov. 3-6, 2008.

[34] A.H. Omidi, M.R. Sharifmogadas, Evaluation of Iranian safflower cultivars reaction to different sowing dates and plant densities, World Appl. Sci. J. 8 (2010) 953-958.

[35] A. Tayebi, H. Afshari, F. Farahvash, J.M. Sinki, S. Nezarat, Effect of drought stress and different planting dates on safflower yield and its components in Tabriz region, Iran. J. Plant Physiol. 2 (2012) 445-453.

[36] R.J. Mailer, T.D. Potter, R. Redden, J. Ayton, Quality evaluation of safflower (Carthamus tinctorius L.) cultivars, in: Proc. 7th Int. Safflower Conf., Wagga Wagga, Australia, Nov. 3-6, 2008.

[37] M. Akçura, F. Partigoç, Y. Kaya, Evaluation of drought stress tolerance based on selection indices in Turkish bread wheat landraces, J. Anim. Plant Sci. 21 (2011) 700-709.

[38] H.M. Akram, A. Ali, A. Sattar, H.S.U. Rehman, A. Bibi, Impact of water deficit stress on various physiological and agronomic traits of three Basmatic rice (Oryza sativa L.) cultivars, J. Anim. Plant Sci. 23 (2013) 1415-1423.

[39] A. Nabloussi, M. El Fechtali, Agronomic and technological evaluation of a world safflower collection under Moroccan conditions, Al Awamia 121/122 (2010) 4-16.

[40] E. Cazzato, L. Borazio, A. Corleto, Grain yield, oil content and earliness of flowering of hybrids and open-pollinated safflower in southern Italy, in: Proceed. 5th Int. Safflower Conf., Williston, North Dakota, USA, July 23-27, 2001.

[41] K. Alizadeh, J. Carapetian, Genetic variation in a safflower germplasm grown in rainfed cold drylands, J. Agron. 5 (2006) 50-52.

[42] R.C. Johnson, B.P. Ghorpade, V.L. Bradley, Evaluation of the USDA core safflower collection for seven quantitative traits, in: Proc. 5th Int. Safflower Conf., Williston, North Dakota, USA, July 23-27, 2001.

[43] S.M. Malleshappa, I. Hiremath, R.I. Ravikumar, Negative associations between important quantitative traits in safflower (Carthamus tinctorius L.), Sesame Safflower Newsl. 18 (2003) 80-84. 